\title{
Stage I Hypopharyngeal Carcinoma AJCC v6
}

National Cancer Institute

\section{Source}

National Cancer Institute. Stage / Hypopharyngeal Carcinoma A/CC v6. NCI Thesaurus. Code C8038.

Stage I includes: T1, N0, M0. T1: Tumor limited to one subsite of the hypopharynx and 2 $\mathrm{cm}$ or less in greatest dimension. N0: No regional lymph node metastasis. M0: No distant metastasis. (AJCC 6th ed.) 